研究

\title{
超硬合金摺動面の微細き裂発生機構
}

\author{
松田 健次的, 今里 州一视, 德本啓的, 兼田 楨宏的1

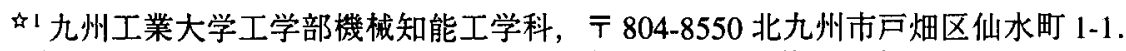 \\ か2 日本タングステン(侏)， テ 841-0203 佐賀県三盖基郡基山町大字園部 3173-2.
}

\section{Study on Occurrence of Shallow Cracks on Rubbing Surface of Cemented Carbide}

\author{
Kenji Matsuda ${ }^{\text {t } 1}$, Shuichi Imasato ${ }^{\text {t2 }}$, Kei Tokumoto ${ }^{\text {古 } 2}$ and Motohiro Kaneta ${ }^{\text {मे } 1}$ \\ ${ }^{2}$ 1 Dept. Mechanical and Control Eng., Fac. Eng., Kyushu Institute of Technology, 1-1 Sensui-cho, Tobata, Kitakyushu 804-8550. \\ ${ }^{2}$ Nippon Tungsten Co., Ltd., 3173-2 Sonobe, Kiyama-cho, Miyaki-gun, Saga 841-0203.
}

Received December 25, 2000

\begin{abstract}
SYNOPSIS
A possible mechanism for the occurrence of numerous shallow cracks, which were observed on the rubbing surface of cemented carbide, was studied The experiments were conducted using an apparatus simulated mechanical face seal composed of two kinds of ceramics rings and cemented carbide ring, with distilled water as the liquid to be sealed. The variations of rubbing surfaces of cemented carbide were examined in detail by using the Vickers indentations. Although the crack spacing gradually decreased with increasing the number of cracks, new crack was hardly formed between the precracks if the crack spacing fell below a critical value. If the Vickers indentation tests were conducted on the rubbing surface where the crack spacing was larger than the critical value, indentation cracks with almost the same length as the neighboring precracks could be formed. It was also found that the surface near the crack piled up in both cases where the crack was caused by rubbing test and by the Vickers indentation test. These results suggested that the cracking occurred by the tensile residual surface stress. A method to predict the magnitude of the tensile residual stress by measuring the surface profile was also proposed.
\end{abstract}

KEY WORDS

cemented carbide, surface cracking, indentation crack, residual stress, friction

\section{1 緒 言}

強勒さと酎摩耗性を合わせ持つ超硬合金は, 各種機械の機 能・性能・信頼性を支える代表的なトライボ材料としての地 位を確保しつつある。しかし，超硬合金は超硬合金を含む他 の硬質材料としゅう動させると，通常，超硬合金表面に多数 の微細き裂がしゅう動方向と直角方向に発生する久点を持っ ている．超硬合金がトライボ材料として真に機能するために は，そのき裂発生機構の解明と発生防止方法の確立が必要不 可欠である.

従来、このようなき裂の発生は熱応力によると説明されて

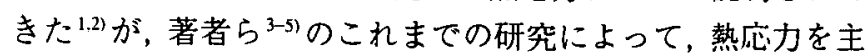
要因とする説では必ずしも実験事実を説明することができな いこと，また高い接線力を伴った接触荷重の機械的作用がき 裂発生に不可欠であることが明らかにされた。ただし，この 理論の正否を判定する鍵となるしゅう動面の接触状態やき裂 の発生機構については必ずしも明確にされていない.
そこで本研究では，微小ビッカース圧痕を利用して超硬合 金表面の変化を詳細に観察することにより，き裂発生機構の 検討を行った。

\section{2 実験方法}

実験には，Fig.1に示すメカニカルシール実験装置”を用い た. Fig. 2 に試験片形状を示す. 固定側試験片には平均粒子径 約 $0.6 \mu \mathrm{m}$ の超硬合金を，回転側試験片には窒化ケイ素および アルミナを用いた. Table 1に各材料の熱・機械的特性を示す. 固定側試験片はゴムリングを介して液槽底部中央に取り付け られ, 回転側試験片は, 回転軸の上端部にゴムシートを介し て取り付けられている。 しゅう動面押し付け荷重は, 固定側 試験片取り付け主軸上部に掞もりをのせることによって設定 し，しゅう動トルクは液槽から突出したカンチレバーで液槽 の回転を止める力を小型ロードセルで検出することによって 求めた．また，超硬合金試験片には側面より熱電対挿入用の 
穴 (直径 $0.6 \mathrm{~mm}$ ) 開け，しゅう動部中央表面下 $1 \mathrm{~mm}$ の温度 を測定した，奏験は，密封液として蒸留水を用い，室温のも と回転数 $6000 \mathrm{rpm}$ ( 加速時間 5 秒) で実施した。

Fig.3に，実験条件を示す．まず窒化ケイ素を相手材として しゅう動試験を行い，き裂が発生するまで段階的に荷重を増 加させた．き裂発生後，超硬合金表面の付着物を除去する程 度に再研磨し，観察される任意のき裂近傍にビッカース压痕を 付与した．その後，アルミナを相手材としてしゅう動実験を 行いき裂発生状況を調べるとともに, $\mathrm{CCD} メ ラ$ 付きの3次 元形状測定器を用いて, 同一き裂のしゅう動による表面形状

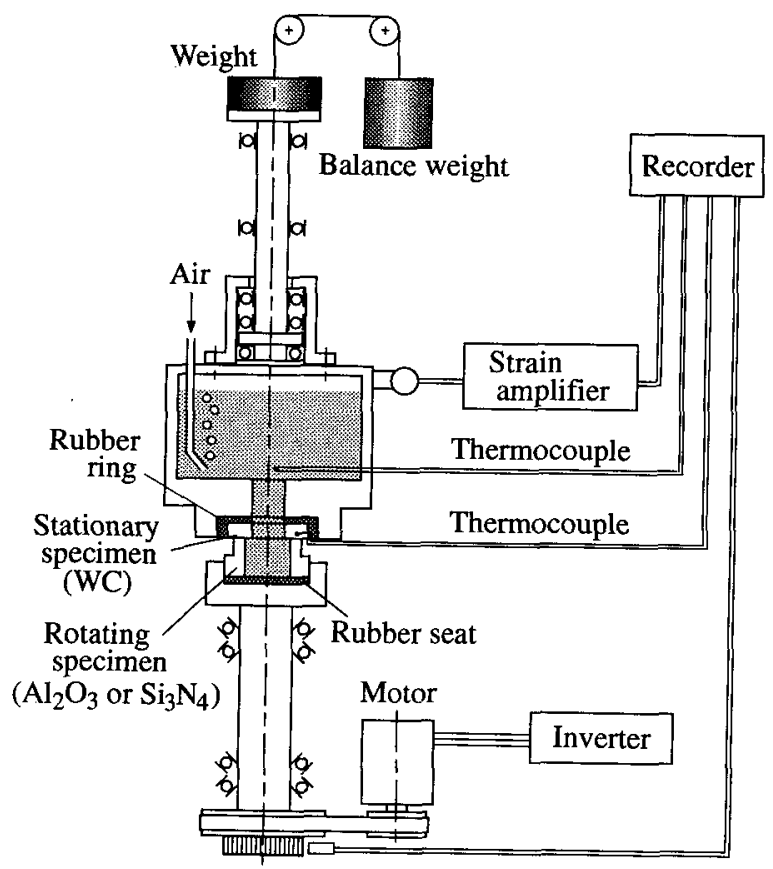

Fig.1 Schematic diagram of experimental apparatus.

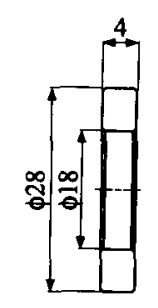

Cemented carbide

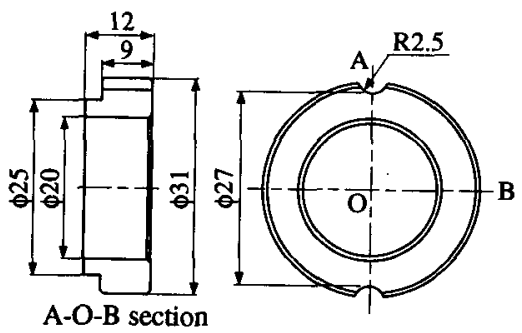

$\mathrm{Al}_{2} \mathrm{O}_{3}$ or $\mathrm{Si}_{3} \mathrm{~N}_{4}$
Fig.2 Shape and dimension of specimens.
変化を圧痕を目印にして調べた。さらに任意の場所にビッ カース圧痕を付与し、压痕き裂の発生状況を調心゙た。なお，一 回の実験でのしゅう動時間は5分を基準としたが，著しい振 動が発生した場合にはその時点で実験を終了した。

\section{3 実験結果}

3.1 摩擦トルクおよびしゅう動面温度の変化

Fig.4に，実験 B5 における摩擦トルク・温度の経時変化を 示す. 実験開始後約 110 秒経過後にトルクは急激に増加して, その值は $0.7 \mathrm{Nm}$ 程度にまで達している。また，それと同時に しゅう動面下温度 (図中 Temp. A) も急增して $100^{\circ} \mathrm{C}$ を超えて

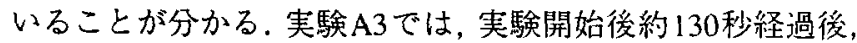

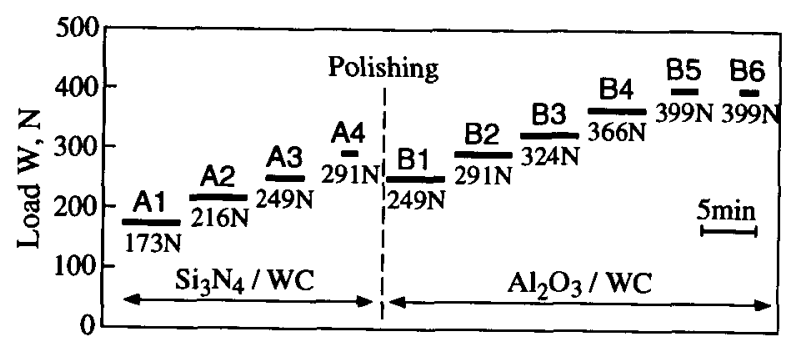

Fig.3 Experimental conditions.

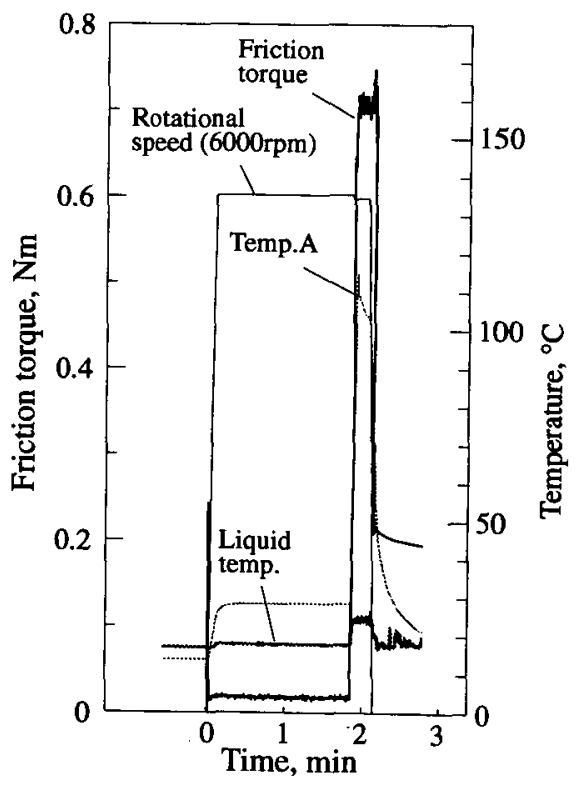

Fig.4 Chart traces of the friction torque, temperature and rotational speed in test B5.

Table 1 Thermo-mechanical properties of specimens.

\begin{tabular}{|c|c|c|c|c|c|c|c|c|c|}
\hline Specimen & $\begin{array}{c}\text { Composition } \\
\text { (Binder content } \\
[w t \%])\end{array}$ & $\begin{array}{c}\text { Apparent } \\
\text { density } \\
\rho \\
{\left[\mathrm{kg} / \mathrm{m}^{3}\right]} \\
\end{array}$ & $\begin{array}{c}\text { Hardness } \\
H V\end{array}$ & $\begin{array}{c}\text { Bending } \\
\text { strength } \\
\sigma_{b} \\
{[\mathrm{GPa}]}\end{array}$ & $\begin{array}{c}\text { Elastic } \\
\text { modulus } \\
E \\
{[\mathrm{GPa}]}\end{array}$ & $\begin{array}{c}\text { Poisson's } \\
\text { ratio } \\
v\end{array}$ & $\begin{array}{c}\text { Thermal } \\
\text { expansion } \\
\text { coefficient } \\
\alpha \\
{\left[\mathrm{K}^{-1}\right]}\end{array}$ & $\begin{array}{c}\text { Thermal } \\
\text { conductivity } \\
k \\
{\left[\mathrm{~W} / \mathrm{m}^{\circ} \mathrm{k}\right]}\end{array}$ & $\begin{array}{l}\text { Specific } \\
\text { heat } \\
C_{p} \\
{\left[\mathrm{~J} / \mathrm{kg}^{\bullet} \mathrm{K}\right]}\end{array}$ \\
\hline WC & WC-Co (15) & $13.9 \times 10^{3}$ & 1550 & 3.1 & 540 & 0.24 & $6.0 \times 10^{-6}$ & 67 & 210 \\
\hline $\mathrm{Si}_{3} \mathrm{~N}_{4}$ & & $3.3 \times 10^{3}$ & 1660 & 1.1 & 314 & & $3.6 \times 10^{-6}$ & 25.1 & 712 \\
\hline $\mathrm{Al}_{2} \mathrm{O}_{3}$ & $\mathrm{Al}_{2} \mathrm{O}_{3}: 99 \%$ & $3.92 \times 10^{3}$ & 14801500 & ${ }^{0.410}{ }_{\sim 0.438}$ & 342 & 0.27 & $6.49 \times 10^{-6}$ & 27.9 & 916 \\
\hline
\end{tabular}


また実験 A4 では，実験開始直後から Fig.4の後半と同様な高 トルク (最大 $0.6 \mathrm{Nm}$ 程度) と振動が発生したため, A3ではしゅ う動時間約 150 秒で, またA4 は約 40 秒で実験を終了した. 実 験 B6 は実験 B5 と同じしゅう動面押し付け荷重であるが, 実 験開始直後から測定可能トルク $(0.8 \mathrm{Nm})$ を超える摩擦トルク が発生したため, 約 90 秒経過後実験を終了した。

その他の実験条件においては，一瞬トルクが上昇した場合 (A1, B2) や実験開始直後の 20 秒間程度のみ高トルクの状態が 継続した場合(B1)があったが, 全体的にはFig.4の前半にみら れるような, $0.02 \mathrm{Nm}$ 以下の低トルクで安定した状態が設定時 間の 5 分経過するまで続いた.

3.2 き裂の発生状況

実験A3終了後のしゅう動面には半径方向に伝ぱしたき裂が 1 本観察され，A4終了後にはき裂は10本程度に増加した。こ の状態では，き裂は 1 本または数本ずつのかたまりとなって 離散的に存在していた。

アルミナを相手材に変えた後, 実験 B2, B5, B6 の終了後に しゅう動面を観察したところ，いずれの場合もき裂の数が増 加していることが確認された. Fig.5に, 実験 B2 およびB5 終 了後のしゅう動面の例を示す. Fig.5 (a)には薄いしゅう動痕が 観察されるが, Fig.5(b)ではその部分の色がさらに濃くなり新 たなき裂が3本半径方向に伝ぱしている。 また, Fig.6に, 実 験B6による超硬合金しゅう動面の変化例を示す.き裂はFig.5 と同様に, 主にしゅう動こん内に存在し, 半径方向に伝ぱし ている.また，既に存在するき裂の間に新たなき裂が発生し， その数が増加していることが分かる。ただし，新たなき裂は
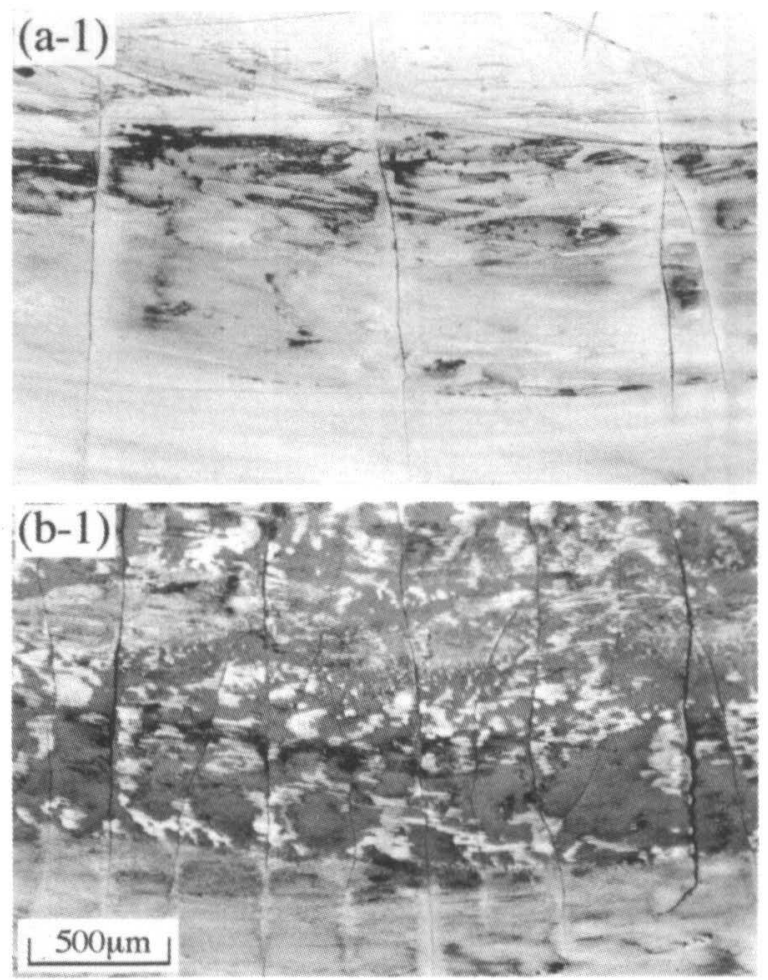

き裂間隔がある程度広いところにのみ発生し, Fig.6(b-2)に示 すように, き裂間隔が比較的狭い $(250 \mu \mathrm{m}$ 程度 $)$ ところには発
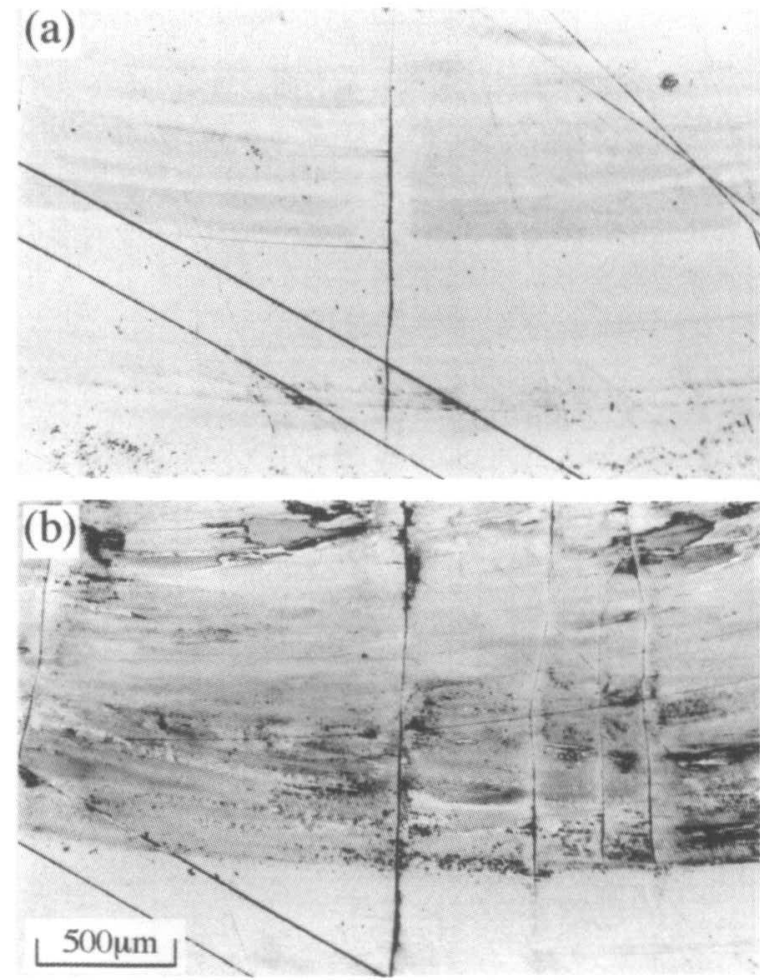

Fig.5 Comparison of the rubbing surface: (a) after test B2, (b) after test B5.
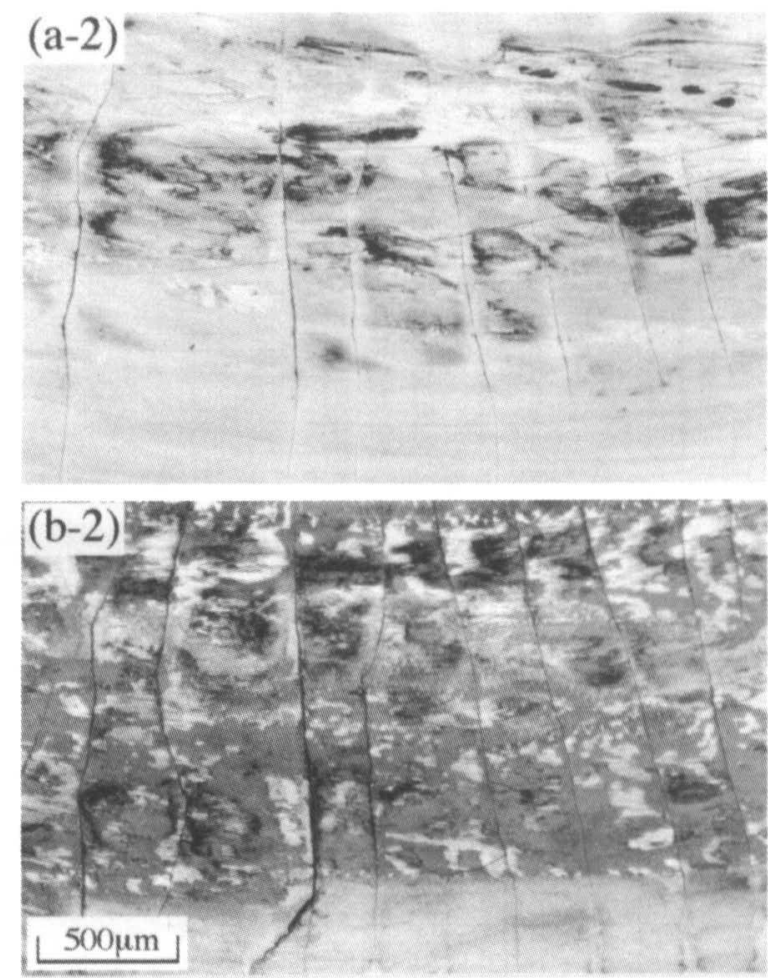

Fig.6 Comparison of the rubbing surface: (a) after test B5, (b) after test B6. 
生していない.なお，隣接したき裂の長さはほぼ等しく，そ の長さがしゅう動痕幅と同程度にまで達しているものが多く 観察された。

Fig.7 は, 実験 B5 およびB6 終了後のしゅう動面を円周方向 に 15 度間隔 (全 24 視野) で写真撮影を行い, 各視野で観察さ れたき裂本数の変化を示したものである.各視野の大きさは, 円周方向に $2.86 \mathrm{~mm}$, 半径方向に $1.90 \mathrm{~mm}$ であり, 24 視野で円 周方向のほほ全域をカバーしている。実験 B5 の終了後では, き裂の発生本数は観察場所によってかなり異なっているが, 実験B6後ではいずれの視野においても9本前後のき裂が発生 していた.

なお, 実験B6終了後に試験片を切断してき裂断面を観察し たところ, ほとんどの場合き裂は表面にほほ垂直に進展して おり, 深さが50 100 $\mu \mathrm{m}$ 程度に達しているものが多く観察さ れた。 ただし， $100 \mu \mathrm{m}$ 程度を超える深いき裂では，き裂が進 展するにしたがい, 次第に表面に平行な方向に向きを変えて いるものも認められた.

\section{3 ビッカース圧痕き裂の観察}

実験B5の終了後, 周囲にき裂が存在していないしゅう動痕

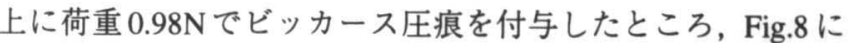
示すように半径方向に圧痕き裂が発生し，その長さはしゅう 動痕幅と同程度となった. Fig.9 に実験 B6 終了後のしゅう動 面の, 圧痕付与による変化の例を示す. 圧痕付与前にこの視

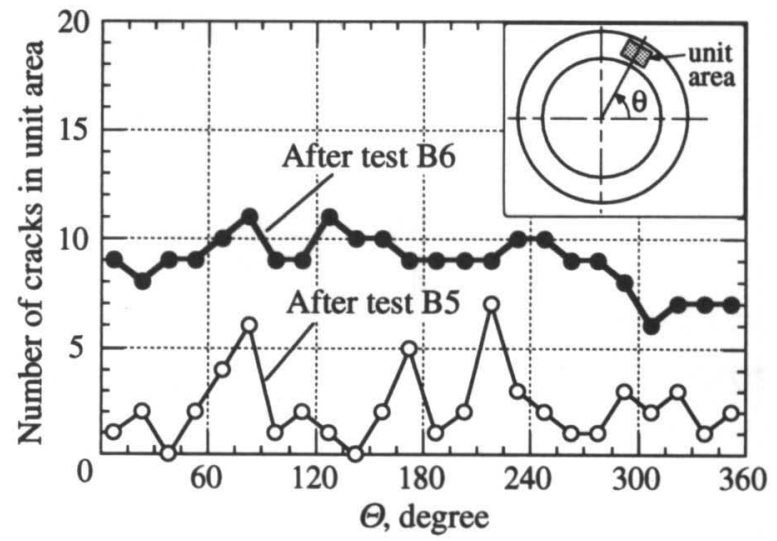

Fig.7 Distribution of the number of cracks observed in the unit area $(2.86 \times 1.90 \mathrm{~mm})$.

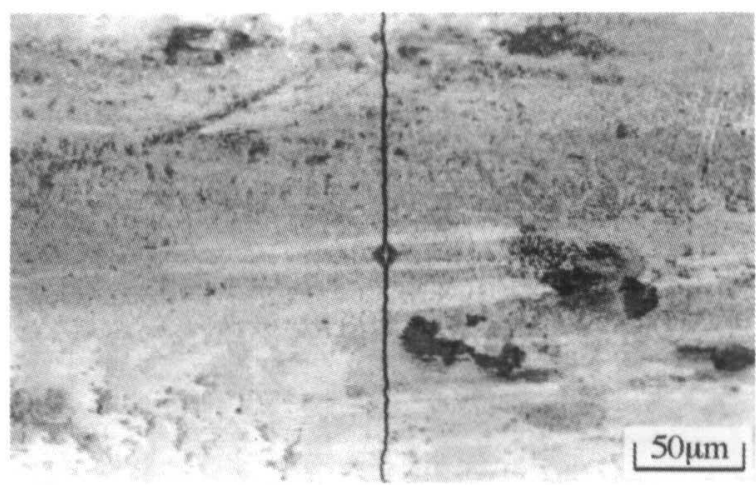

Fig.8 Indentation crack (indentation load $\mathrm{P}=0.98 \mathrm{~N}$, after test B5).
野内に存在するき裂は7本(分岐き裂は除く)であり, 実験B6 終了後のしゅう動面に観察される平均き裂本数 (9本) より少 ない.き裂間隔が広い $(600 \mu \mathrm{m}$ 程度 $)$ ところのほぼ中間に荷重 $9.8 \mathrm{~N}$ でビッカース圧痕を付与した場合には, 圧痕がしゅう動 幅のほほ中央 (圧痕 A) あるいはしゅう動幅の端近傍 (圧痕B) にあっても, 両隣りのき裂と同程度の長いき裂が半径方向に 発生した. 一方, 写真右部のき裂間隔が $500 \mu \mathrm{m}$ 程度のところ のほぼ中間にビッカース圧痕 (圧痕 $\mathrm{C}$ : 荷重 $9.8 \mathrm{~N}$ ) を付与した ところ, 両隣りのしゅう動き裂より若干短いき裂(長さ $900 \mu \mathrm{m}$ 程度)が発生した. さらに, この圧痕としゅう動き裂の中間に 同じ荷重でビッカース圧痕を付与したが, 圧痕き裂の発生は 認められなかった. なお, 荷重 $9.8 \mathrm{~N}$ で圧痕を付与する前に, $0.49 \mathrm{~N}$ および $0.98 \mathrm{~N} て ゙$ 痕を円周方向に $50 \mu \mathrm{m}$ 間隔で付与した が、いずれの圧痕からもき裂の発生は認められなかった。

しゅう動き裂の間隔が狭い $(250 \mu \mathrm{m}$ 以下 $)$ ところに圧痕を付 与した場合には, 荷重が9.8Nにあってもほとんどの場合圧痕 き裂は発生せず, き裂が発生しても $10 \mu \mathrm{m}$ 程度の短いもので あった. 非しゅう動部に圧痕を付与した場合には, $0.49 \mathrm{~N}, 0.98 \mathrm{~N}$, $9.8 \mathrm{~N}$ のいずれの荷重においても, 上記のような圧痕き裂は発 生しなかった.

3.4 き裂の表面形状

Fig.10に, 実験B5 で新たに発生したき裂の断面形状を，ま たFig.11にFig.8に示した圧痕き裂の断面形状を示す．き裂が 発生した部分は, しゅう動き裂でも圧痕き裂でも周囲よりも 隆起していることがわかった.
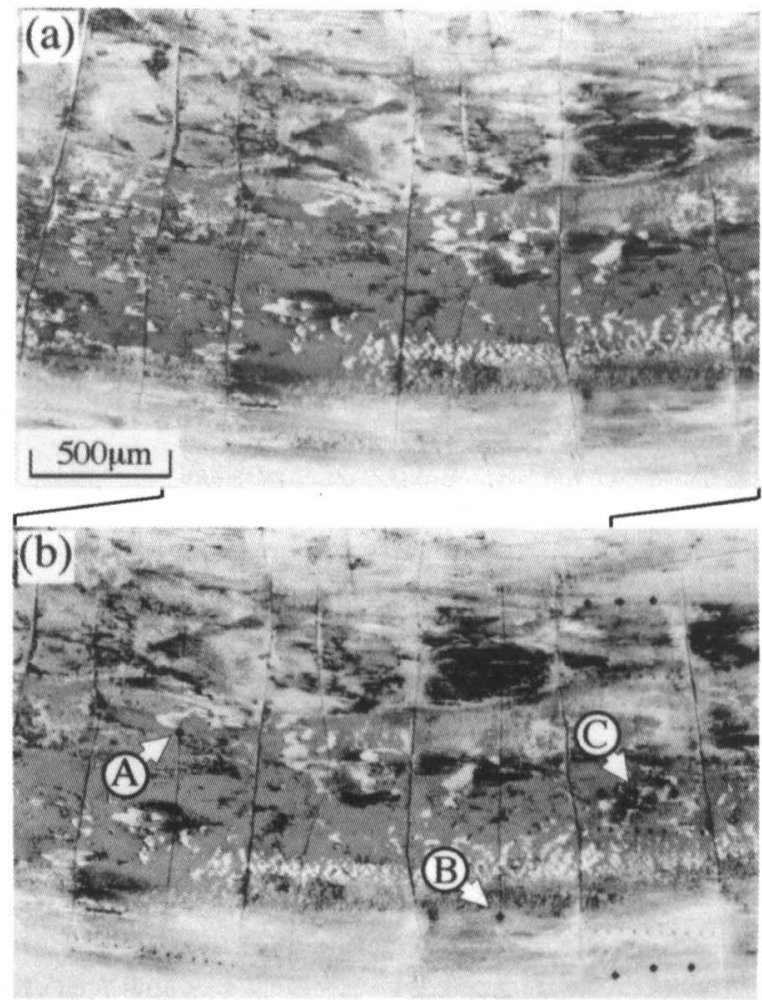

Fig.9 Variation of rubbing surface by the Vickers indentation test: (a) after test B6, (b) after the Vickers indentation test. 

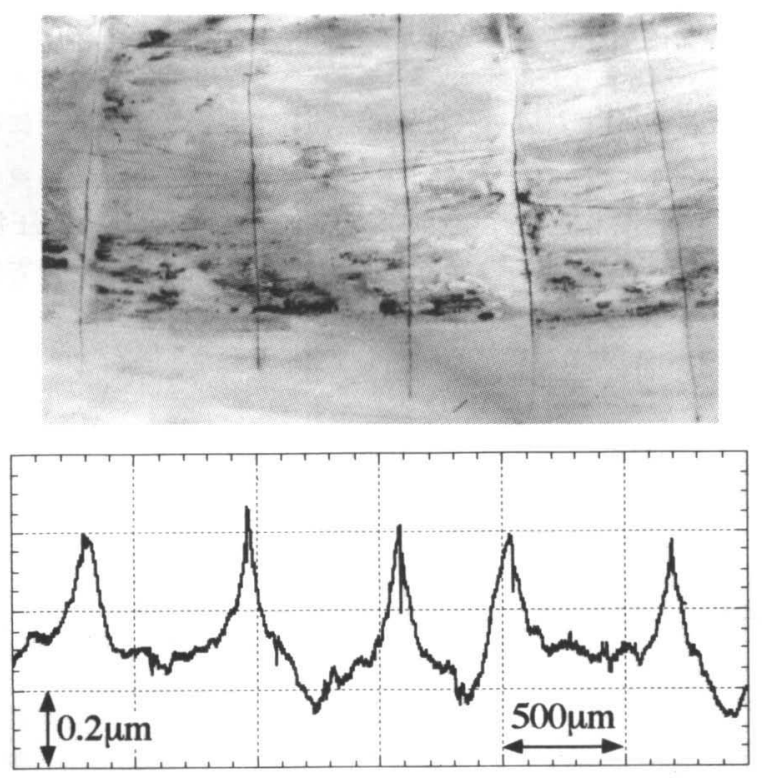

Fig.10 Surface profile of cracking surface after test B5.

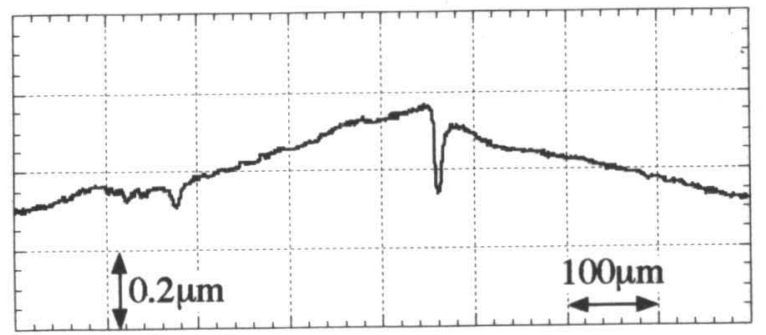

Fig.11 Surface profile corresponding to the indentation crack shown in Fig.8.

なお, 実験 A4で発生したき裂の表面再研磨後の表面形状 と, 実験B2後の表面形状を比較したが, 顕著な違いは認めら れなかった。

\section{4 考察}

圧痕き裂の結果は, しゅう動部には円周方向に強い引張残 留応力が存在し, これがき裂発生に寄与した可能性が高いこ とを示唆している。ただし，ある程度以下にき裂間隔が狭 まった場合には, その間にはしゅう動き裂も圧痕き裂も発生 し難くなった。 すなわち, き裂が発生するとその近傍の引張 応力は緩和され, 低下するために, ある程度以下に間隔が狭 まると新たなき裂は発生し難くなる。 そのため, しゅう動試 験を繰り返すごとにき裂間隔は低下していくものの, 最終的 にはほほ一定の間隔に落ち着くものと考えられる. Fig.7に示 したように, 実験 B6 終了後には 1 視野当たり9本のき裂が観 察される場合が最も多くなったが，これから求めた平均き裂 間隔は $320 \mu \mathrm{m}$ 程度となる.き裂間隔が $250 \mu \mathrm{m}$ 程度以下のとこ ろでは新たなき裂が発生しなかったことをあわせて考慮する と, 実験B6によってしゅう動面の全周にき裂がほほ限界に達 するまで密に発生し，そのために各視野でほほ一定の本数の
き裂が観察されたものと考えられる.

さらに，き裂間隔が比較的広いところにビッカース圧痕を 付与すると, たとえ圧痕がしゅう動幅の端近傍にあっても周 囲のき裂と同程度の長さのき裂が発生するという事実は, 何 らかのき裂発生起点が存在すると, き裂は引張残留応力が存 在する範囲に一挙に進展してしまう可能性が高いことを示唆 している.すなわち,この結果から，隣接するき裂の長さは ほほ同じであること，また，松井ら ${ }^{6)}$ が報告しているように， すでに発生しているき裂はその後のしゅう動によってほとん ど伝ぱしない理由が理解できる。ただし，しゅう動痕はみか けの接触面に一様に形成されるのではなく, 特に実験の初期 の段階では, 明確なしゅう動痕が認められない場所や, みか けの接触面幅よりかなり狭い場所などが存在した，すでにき 裂の発生しているしゅう動痕の幅が再しゅう動によって増加 した場合には，き裂が大きく伝ぱすることも確認された。な お, Fig.5(a)にみられるき裂は, 実験B1 またはB2で新たに発 生したものであるが, Fig.5(b)のしゅう動痕幅よりき裂がかな り長いのは, 実験 $\mathrm{A} 4$ によってこのき裂の範囲まで残留応力が 蓄積され, 実験 B1 または B2 中に生じた短時間の直接接触が 引き金となって一挙にき裂が伝ぱしたのではないかと考えら れる.

また，既に存在しているき裂の断面形状はしゅう動によっ ても大きく変わらないこと, 圧痕き裂は周囲より隆起してい ることから判断して, き裂部の隆起は引張残留応力下でき裂 が発生したことにより生じた可能性が高いと考えられる。 そ こで, 前報4.5)の解析法を利用して, 残留応力がき裂部の表面 形状に与える影響について検討を行った. Fig.12に解析モデ ルを示す。き裂は, 前報で使用した有限要素解析領域の表面 中央に垂直に作成した. 最小要素の一辺はき裂長さc $\mathrm{c} 1 / 5$ で あり, 解析領域の寸法は, 幅方向に $290 \mathrm{c}$, 深さ方向に $120 \mathrm{c}$ と した. Fig.13は, き裂発生前に与えた残留応力分布であり, 仮 想の熱ひずみを与えることによって A，Bの2つの場合を仮定 した. A は, 一様な引張残留応力が存在する場合, Bは表面か らき裂先端に向かって直線的に応力が減少する場合である。 Fig.14に, Fig.13に示した残留応力下でき裂が発生したことに よるき裂近傍の表面形状の変化を示す. A, B ともにき裂部は 隆起することが分かる. B の場合の隆起高さはAより低いも のの，その差は 2 割程度である.

ここで, Fig.11のき裂部の隆起高さは $0.2 \mu \mathrm{m}$ 程度であるが, き裂深さを $100 \mu \mathrm{m}$ と仮定し, またヤング率を $\mathrm{E}=540 \mathrm{GPa}$ とし

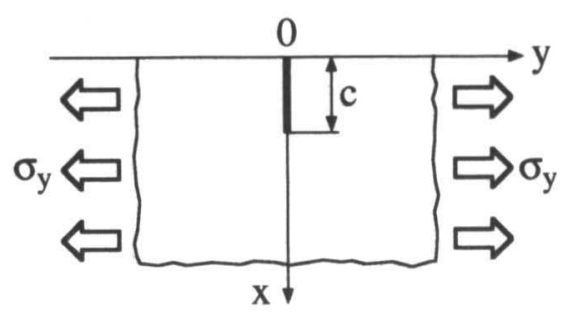

Fig.12 Analytical model. 


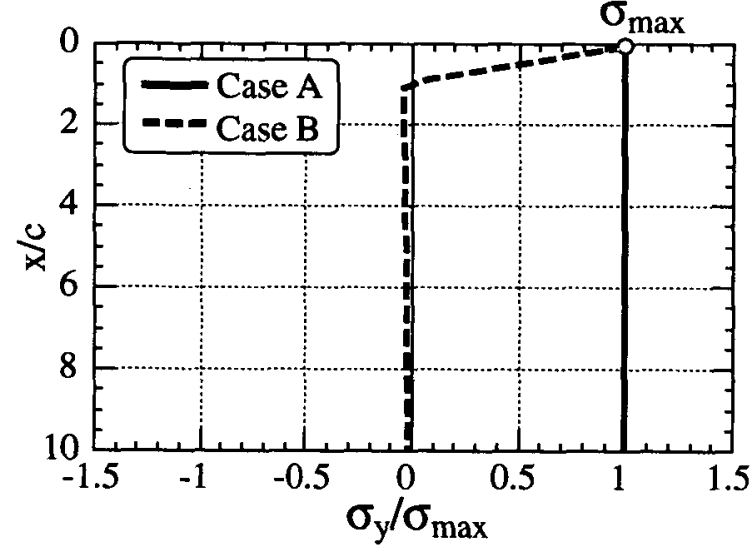

Fig.13 Residual stress distributions assumed in the analysis

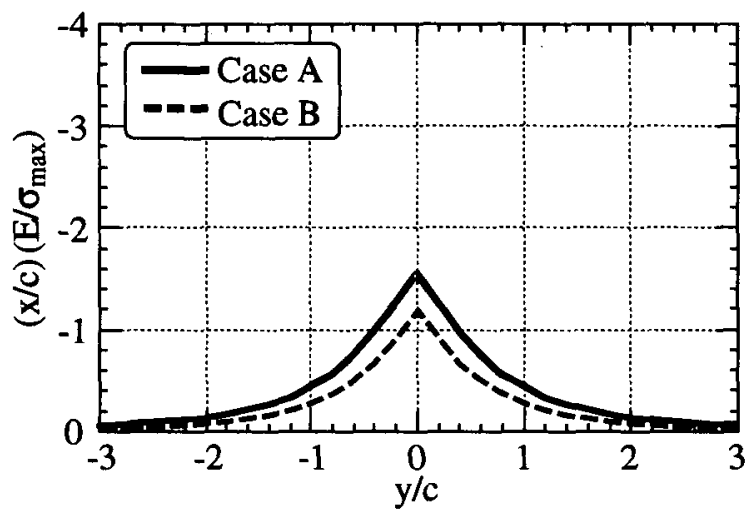

Fig.14 Predicted surface profile of cracking surface.

て, き裂発生前の残留応力を Fig.13の A から逆算して推定す ると, $\sigma_{\max }=700 \mathrm{MPa}$ 程度となる。松井らあは，X線回折によっ て超硬合金しゅう動面の残留応力を測定し，き裂部にはしゅ う動方向に $200 \mathrm{MPa}$ 程度の引張残留応力が存在することを明 らかにしている，材料や実験条件が異なるため単純に比較で きないかもしれないが，き裂発生によりき裂近傍の引張応力 が緩和され減少することを考慮すると，松井らの実験におい

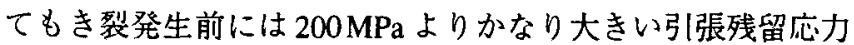
が存在していた可能性が高いといえる。この結果は，き裂部 の隆起現象を利用すれば，しゅう動き裂や圧痕き裂から残留 応力を推定できる可能のあることを示唆している。

なお，本実験の過程において，しゅう動前に付与していた 圧痕が，し四動後にもあまり変化していない場合や，消え
て確認できなくなる場合があった，压痕が消えた周辺には強 いしゅう動痕が認められ，また新たなき裂もそのような場所 に発生する傾向が強加た。すなわち，局部的に極めて強い 接触が生じていると考えられ，それがしゅう動トルクの増大 ならびにき裂発生に深く関与しているものと考えられる。

\section{5 結 論}

（1）超硬合金しゅう動面に観察されるき裂は, 一度に多数発生 するのではなく,最初に発生したき裂の間に新しいき裂が 発生し, 徐々にその間隔は狭くなる。

（2）しゅう動部には強い引張残留応力が存在し,何らかのき裂 発生起点が存在すると，き裂は引張残留応力が存在する範 囲に一挙に進展する可能性が高い。

（3）き裂が発生すると，き裂近傍の引張応力は緩和されるた め,き裂間隔がある一定の值より狭まると新たなき裂は発 生し難くなる。

（4）き裂発生部は周囲上り隆起しているが,この隆起は引張残留 応力下でき裂が発生したことにより生じた可能性が高い，

\section{謝 辞}

最後に, 本研究に協力された平成 10 年度卒論生中尾主二郎 君に感謝する。

文献

1) E.Mayer: Mechanical Seals, Burgmann, (1977)128.

2) F.E.Kennedy and S.A.Karpe: "Thermocracking of a Mechanical Face Seal", Wear, 79(1982)21-36.

3) 松井伸悟, 藤井謙太郎, 松田健次, 兼田楨宏: "メカ二カル シール超硬合金しゅう動リングのき裂発生機構( 第 1 報、 き裂発生に及ほす寸諸因子の影響)", 日本機械学会論文集 $(\mathrm{C}$ 編 ),61(1995)3672-3677.

4) 松田健次, 松井伸悟, 久我栄誉, 兼田楨宏: "メカ二カル シール超硬合金しう動りングのき裂発生機構(第2 報、 理論的考察)", 日本機械学会論文集 (C 編 ), 61(1995)3678 3684.

5) 松田健次, 縄本大網, 兼田楨宏, 今里州一, 德本啓: "メ力 ニカルシール超硬合金しゅう動りングのき裂発生機棈(第 3 報, 熱弾塑性解析による諸因子の評価)", 日本機械学会論 文集 (C 編)，65(1999)1193-1200.

6) 松井伸悟, 内堀善吉, 兼田楨宏: "メカニカルシールにおけ る超硬合金しゅう動りングのき裂発生に及ぼす残留応力の 影響", 日本機械学会諭文集 (C 編), 59(1993)3481-3487。 